\title{
The Role of Modern Education in Physical Education
}

\author{
Yufang Wu \\ Jiangxi College of Foreign Studies
}

Keywords: Colleges and universities; Physical education; Modernization; Role

\begin{abstract}
Towards the process of modernization in China, the enhancement of the individual quality of modern builders and people's own modernization are especially important. The full, free and comprehensive development of ability is the core of the modernization of people. Combined with the ability structure of modern people, we found that physical education has a unique role. School sport modernization does not only play an important role in promoting the modernization of education and the process of sports modernization, it also clears its connotation from the modernization of school physical education ideas and concepts, the modernization of education content and education method, the modernization of the team, the modernization of management, the modernization of conditions, the modernization of evaluation system and so on; it also seizes from value orientation and evaluation basis, the value orientation of national development, the value orientation of individual development, the value orientation of democratic development and the value orientation of efficiency development, etc. It is conducive to the further implementation of the moderate advance, balanced development and coordinated development strategy of the modernization in school sports and the full realization of the modernization of school sports
\end{abstract}

\section{Introduction}

The modernization of the world began in the 17th century in Western Europe, and then spread to the rest of Europe and North America. Since the 20th century, almost all countries and regions of Asia, Africa and Latin America also successively started or tried to start the modernization process, and gradually involved in all walks of life, which had a far-reaching influence on sports. On one hand, social modernization has promoted the modernization of sports; on the other hand, the realization of sports modernization has driven the social modernization to move forward. They are mutually dependent, mutual influence and promote each other. It can be said that the perfect modern society must include the sports modernization, and the society without sports modernization is not the perfect modern society.

With the development of education, school sports gradually became the important content and methods of education to promote students' physical and mental health development. The rich and advanced culture and traditional culture education of school sports became an important way to cultivate students' humanistic spirit, which has increasingly prominent and important status and role of education. Moreover, the school physical education is also an important link for students to carry out modern life style education, which is a joint for students and nature, school and the society. School physical education is the important link to promote international cooperation and exchange. The development of the society and the times force sports and education must realize modernization, and sports modernization and education modernization also require the modernization of the school physical education. Therefore, school sports modernization does not only play and important role in promoting the modernization of education and sports, it is also very important in the complete realization of China's social modernization.

\section{The Unique Role of Physical Education in the Process of Human Modernization}

With the Olympics is increasingly warming in China, sports more and more in people's lives occupies important position in carrying out quality education, especially in the process of modernization we found that sports have a rich and unique value.

1. Physical education is the basis of modern people's body. According to the research, regular 
exercise can increase bone blood supply, promote bone growth, and have a very important significance to the growth and development of young people; Exercise can also enhance muscle strength, endurance and coordination; Exercise also has a good promoting role for the nervous system and digestive system function.

2. Sports can cultivate the sense of competition of modern people. Modern society is inseparable from the competition, no matter the state, enterprise, collective, or ordinary worker is in intense competition for survival and development. Competition is the soul of modern sports. The competition education in sports activities is better than any other activities, it can enable participants to experience the atmosphere of intense competition in sports

3. Sports help to promote the intelligence development and improve learning efficiency of modern people's. Physiology tell us often participating in sports activities can improve the human central nervous system, improve the cerebral cortex excitatory and inhibitory role of coordination and strength the nervous system excitatory and inhibitory alternation process, so as to improve the balance and accuracy of the cerebral cortex of the nervous system, promote the development capabilities of human perception and improve and increase thinking flexibility, coordination and reaction speed.

\section{The Advantages of Modern Education in Physical Education}

1. Provide visual material and can improve the motor skills of students. The most important task of physical education is to let the students master sports skills, cultivate students' comprehensive quality. And the use of new media means to carry out junior middle school sports teaching can achieve the visual effect from the image required by teachers and improve the efficiency and quality of physical education, as well as help students master more sport skills and learn more physical movements.

2. Can effectively stimulate students' learning interest and enthusiasm. The so-called interest and enthusiasm is the key factor in the process of learning. Only under the guidance of spontaneous interest, students can learn themselves and profoundly master physical knowledge and skills. The use of new media teaching means make teachers can show students rich, colorful and vivid teaching material contents and images, in order to attract students' attention.

3. Use modern technology to explain and improve the quality of teaching. In the traditional sports teaching, due to the complexity of the most technical actions, explain the technical essentials and demonstrate the technology action shall be done separately. New media is advantageous to improve the comprehensive ability of students to analyze problems and solve problems. By means of new media teaching, teachers can repeatedly show students the actions and parts which are different and east to make mistakes, let students have an in-deep experience, carry out discussion these problems and correct mistakes.

\section{The Promotion Strategy of College Sport Modernization}

The content of college physical education is related to the effect and quality of college physical education. The modernization of the content of college physical education is the materialized reflect of the core and core concept of college sports modernization. The contents of college physical education refer to the teaching contents and experience materials used by teachers and students, mainly including the modern curriculum system, teaching material content, and teaching methods and means.

1. Grasp the value orientation of school sports modernization

Whether the value orientation is correct or not directly determines the people's thinking, the success or failure of an action. The value orientation of the physical education in schools in our country can help us to dialectically and objectively understand the judgment of gains and losses and summary of experience of the school sports development, initially establish a standards of the school physical education system and value orientation which adapts to social development and lay a solid foundation for the further reform and development of school sports in the new century. 


\section{Moderate advance strategy}

The modernization of the thought and the concept are the forerunner of school sports modernization and is in global, basic and leading status in promoting the process of modernization of school sports. And the advance of the thought and the concept of school sports education is the premise of realizing the modernization of school sports.

\section{Balanced development strategy}

At the present stage, the advanced concept of physical education in our country slowly transfers to practice. Education investment and resource allocation is not reasonable. The conditions for running schools and teachers are unbalanced. Competitive sports occupy a large number of sports resources. Compulsory and non compulsory education development is not balanced and school sports development environment and supporting legal system is not perfect.

4. Coordinated development strategy

The coordinated development of the internal and external of college sports modernization of mainly refers to make college sports coordinately develop with lifelong sports, community sports as well as competitive sports. College physical education bears the task of college education and shall lay the foundation for lifelong sports. College sports provide guidance, counseling, planning and training for community sports, community sports provide curriculum resources, education environment and other conditions. College physical education lays a foundation for the improvement of the level of sports in the course of the socialization and club. National high level sports provide a platform for the balanced development of the two.

\section{Conclusion}

College sports modernization plays an important role in promoting the modernization of sports and the process of education modernization. The connotation of school sports modernization mainly includes the modernization of the school physical education thought and idea, the modernization of education content and method, the modernization of team, the modernization of management of school sports, school the modernization of school sport condition and the modernization of school sports evaluation system. The value orientation of the country's development, the value orientation of individual development, the value orientation of democratic development and the value orientation of efficiency development provide an important guiding role for the implementation of the school sports modernization strategy. The implementation of the moderate advance, balanced development and coordinated development strategy of school sports modernization provides the reference of the development ideas for the comprehensive promotion of school sports modernization.

\section{References}

[1] Barton G V. The Role of Homework in Helping Students Meet Physical Education Goals [J]. JOPERD--The Journal of Physical Education, Recreation \& Dance, 2000, 71(5):30-34.

[2] Jia Y C, Araújo D. The role of nonlinear pedagogy in physical education [J]. Review of Educational Research, 2013, 77(3):251-278.

[3] Tsangaridou N, O'Sullivan M. The role of reflection in shaping physical education teachers' educational values and practices. [J]. Journal of Teaching in Physical Education, 1997, $17(1): 2-25$.

[4] Zhang T, Solmon M A, Gu X. The Role of Teachers' Support in Predicting Students' Motivation and Achievement Outcomes in Physical Education [J]. Journal of Teaching in Physical Education, 2012, 31(4):329-343.

[5] Pate R R, Corbin C B, Simons-Morton B G, et al. Physical education and its role in school health promotion. [J]. Journal of School Health, 1987, 57(10):445-50.

[6] Sallis J F, Mckenzie T L. Physical education's role in public health. [J]. Research Quarterly for 
Exercise \& Sport, 1991, 62(2):124-37.

[7] Staniszewski T. The role of early education teachers in physical education [J]. Physical Education \& Sport, 2007, 51:58-60.

[8] Collier D. Increasing the Value of Physical Education: The Role of Assessment [J]. Journal of Physical Education Recreation \& Dance, 2011(7):1-58.

[9] Ramirez J P, Olvera L A, Nijmeijer H, et al. The sympathy of two pendulum clocks: beyond Huygens' observations [J]. Scientific Reports, 2016, 6:1-16.

[10]Livingston L A. Re-defining the Role of Physical Activity Courses in the Preparation of Physical Education Teaching Professionals [J]. Physical Educator, 1995, 53(3):114-121.

[11]Ding Y, Xu J, Yao J, et al. The analyses of risk factors for COPD in the Li ethnic group in Hainan, People's Republic of China [J]. International Journal of Copd, 2015, 10(1):2593-2600.

[12]Krotee M L, Wamukhoya E E. The Role of Physical Education in Child Development. [J]. Kenya Journal of Education, 1986, 3. 